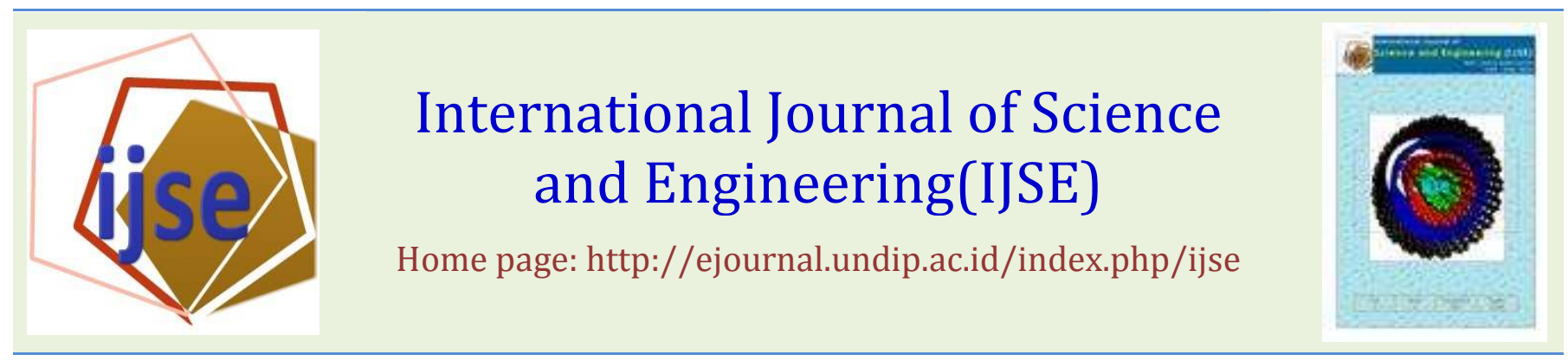

\title{
Distribution of Mean Annual Precipitable Water in Nigeria
}

\author{
Iniobong Anthony Udo and Charity U. Okujagu \\ 1)Department of Physics, Faculty of Science, University of Port Harcourt, Nigeria
}

Email: iudo47@yahoo.com

\begin{abstract}
$\overline{\text { Abstract - Mean monthly precipitable water values from twenty seven state capitals and Federal Capital Territory, Abuja are }}$ determined using a ten year monthly meteorological parameter-average surface temperature. The results are then presented on annual average precipitable water map. The map shows that location with high topography has lowest value of precipitable water while location with plain terrain has highest value of precipitable water.
\end{abstract}

Keywords:mixing ratio; percipitable water; pressure level; surface temperature; topography

Submission: January 20, $2014 \quad$ Correction: April 1, 2014

Accepted: April 11,2014

Doi: $10.12777 /$ ijse.6.2.174-176

[How to cite this article: Udo, I. A, and Okujagu, C. U. 2014. Distribution of Mean Annual Precipitable Water in Nigeria, International Journal ofScience and Engineering, 6(2),174-176. Doi:10.12777/ijse.6.2.174-176]

\section{INTRODUCTION}

Precipitable water by definition is the depth of liquid water that would be obtained if the total amount of water vapour in a specified layer of the atmosphere above a unit area of the earth's surface were condensed to a layer on that surface. The concept of precipitable water has application in many areas such as precipitation forecasting and remote sensing (Oduro-Afriyie, 1989); Atmospheric transmission spectrum (Maduekwe and Ogunmola, 1997). In the light of this, many researchers have developed diverse approaches to understand this concept, precipitable water. These include: Development of precipitable water estimation method using MTSAT measurement. (Akatsukaet-al 2011), Lognormal distribution of precipitable water in Hawii, (Foster and Bevis, 2003), Trends variability in column - integrated atmospheric water vapour (Trenberth et-al, 2005), Atmospheric models, GPS and InSAR measurements of the tropospheric water vapour field over mount Etna (Wadgeet-al, 2002).

In spite of the knowledge about precipitable water and how it affects lives, no attempts in Nigeria have been so far made to map the distribution of precipitable water. Some of the works on precipitable water are found only as a trivial component in works dealing with problems like Estimation of monthly average atmospheric precipitable water vapour in Sokoto and its relationship with the horizontal global solar radiation (Maduekwe and Ogunmola, 1997); Empirical determination of the monthly average atmospheric precipitable water distribution for nine Nigerian locations, (Maduekwe and Iheonu, 1999).
Idemudia and Aro, (1997) also discussed on precipitable water estimation. The purpose of this study is to create a wave in the current literature on precipitable water by determining the mean yearly precipitable water in the atmospheric column and to use same in constructing average annual precipitable water map in twenty seven locations and federal capital territory, Abuja, in which the meteorological data are available.

\section{RESEARCH METHOD}

This work being an extensive research, twenty-eight locations were used. The locations and their geographical coordinates are given in Table 1 . The locations are grouped into two zones starting from (i) Southern and (ii) Northern zones.

The data used in this work were collected from Nigerian Meteorological agency (NiMet) Abuja. The data obtained were ten years (1989-1998) surface maximum and minimum temperatures in degrees Celsius. The average surface temperatures were computed and used for the reading of mixing ratio, m., by following pseudoadiabatic chart from condensation level, $500 \mathrm{mb}$ to $1,000 \mathrm{mb}$ level. From the values of mixing ratio, values of precipitable water for each month at each station were computed using the formula:

$$
\begin{array}{ll}
\mathrm{W} & =\mathrm{m}\left(\mathrm{P} 1_{000}-\mathrm{P}_{500}\right) 1000 \mathrm{~g} \\
\mathrm{Where}: & \\
\mathrm{W} & =\text { Precipitable water }(\mathrm{mm}) \\
\mathrm{m} & =\text { Mixing ratio }(\mathrm{g} / \mathrm{kg}) \\
\mathrm{P}_{1000} & =\text { Pressure level at } 1000 \mathrm{mb} \\
\mathrm{P}_{500} & =\text { Pressure level at } 500 \mathrm{mb}
\end{array}
$$


Table 1: Locations and their coordinates

\begin{tabular}{|c|c|c|c|}
\hline Zone & Location & $\begin{array}{c}\text { Latitude. } \\
\left({ }^{\circ} \mathrm{N}\right)\end{array}$ & $\begin{array}{c}\text { Longitude } \\
\left({ }^{\circ} \mathrm{E}\right)\end{array}$ \\
\hline \multirow{9}{*}{$\begin{array}{l}\text { Southern } \\
\text { zone }\end{array}$} & $\mathrm{P} / \mathrm{H}$ & 04.47 & 06.59 \\
\hline & Calabar & 04.71 & 08.55 \\
\hline & Uyo & 05.00 & 07.50 \\
\hline & Umuahia & 05.25 & 07.30 \\
\hline & Owerri & 05.29 & 07.20 \\
\hline & Asaba & 06.11 & 06.45 \\
\hline & Benin & 06.12 & 05.36 \\
\hline & Enugu & 06.47 & 07.55 \\
\hline & Ikeja & 06.58 & 03.33 \\
\hline \multirow{19}{*}{$\begin{array}{l}\text { Northern } \\
\text { zone }\end{array}$} & Akure & 07.18 & 05.51 \\
\hline & Ibadan & 07.43 & 03.90 \\
\hline & Osogbo & 07.46 & 04.95 \\
\hline & Abeokuta & 07.95 & 03.21 \\
\hline & Lokoja & 06.12 & 07.50 \\
\hline & Makurdi & 07.43 & 08.32 \\
\hline & Illorin & 08.30 & 04.42 \\
\hline & Jalingo & 08.50 & 11.22 \\
\hline & Abuja & 09.00 & 07.32 \\
\hline & Yola & 09.12 & 12.29 \\
\hline & Minna & 09.39 & 06.32 \\
\hline & Jos & 09.87 & 04.97 \\
\hline & Kaduna & 10.00 & 07.45 \\
\hline & Bauchi & 10.37 & 09.80 \\
\hline & Damaturu & 11.44 & 11.57 \\
\hline & Maiduguri & 11.85 & 13.05 \\
\hline & Kano & 12.00 & 08.31 \\
\hline & Katsina & 12.15 & 07.30 \\
\hline & Sokoto & 13.01 & 05.25 \\
\hline
\end{tabular}

The choice of $1000 \mathrm{mb}$ and $500 \mathrm{mb}$ pressure levels was based on the fact that $1000 \mathrm{mb}$ and $500 \mathrm{mb}$ levels are standard levels and hence, conventional data are available for utilization and that energy required to generate buoyancy is found near the earth surface at $1000 \mathrm{mb}$ (Adedokun, 1986). Monthly average values of precipitable water for each station were computed and used to compute for the annual mean values.

\section{RESULT AND DISCUSSION}

\section{(i) Precipitable Water Distribution}

The distribution of precipitable water as presented below is arranged according to latitudinal pattern in the respective zones. For convenience, the country is divided into two zones. The zones include southern and Northern zones, (table 1\&2). In the Southern zone, Abeokuta has the highest value of precipitable water $(18.91 \mathrm{~mm})$ followed by Asaba (18.38mm), Ikeja (18.33mm),Ibadan and Benin $(18.16 \mathrm{~mm})$ each, Umuahia $(18.05 \mathrm{~mm})$, Enugu (17.93mm), Uyo $(17.81 \mathrm{~mm})$, Calabar and Port Harcourt $(17.52 \mathrm{~mm})$ each, Akure $(16.82 \mathrm{~mm})$ and Osogbo $(13.57 \mathrm{~mm})$. In the Northern zone, Sokoto leads with the value, $21.36 \mathrm{~mm}$ followed by Makurdi $(19.88 \mathrm{~mm})$, Yola (19.64mm), Lokoja and Minna (19.53mm) each, Illorin $(18.08 \mathrm{~mm})$, Katsina $(17.72 \mathrm{~mm})$, Abuja $(17.52 \mathrm{~mm})$, Kano $(16.52 \mathrm{~mm})$, Kaduna $(16.25 \mathrm{~mm})$ lastly Jos $(12.84 \mathrm{~mm})$. The results show that precipitable water indices do not follow strictly latitudinal order of arrangement as expected, rather the complex pattern of the precipitable water distribution follows differences in the distribution of land and water bodies (Table 2)

In the Southern zone, the departure of the precipitable water indices from latitudinal order of arrangement could be factored by oceanic influence. The strong, ocean current cell can produce drastic deviation of precipitable water from latitudinal pattern due to great contrast between the warm moist air from the ocean and the cold dry air from the inter-land. The contrast between the two airs therefore produces a front which enhances buoyancy hence; locations that are not even close to coastal line still compete favourably for precipitable water indices with location along the coast.

Table 2: Mean annual precipitable water values computed from monthly mean precipitable water values for twenty eight locations.

\begin{tabular}{|c|c|c|c|c|c|}
\hline Zone & Location & $\begin{array}{l}\text { Lat. } \\
\left({ }^{\circ} \mathrm{N}\right)\end{array}$ & $\begin{array}{c}\text { Long. } \\
\left({ }^{\circ} \mathrm{E}\right)\end{array}$ & $\begin{array}{c}\text { Calculated } \\
\text { precipitable } \\
\text { water, PW } \\
(\mathrm{mm})\end{array}$ & $\begin{array}{c}\text { Annual } \\
\text { Average } \\
\text { PW in } \\
\text { each } \\
\text { zone } \\
\text { (mm) }\end{array}$ \\
\hline \multirow{15}{*}{ South } & $\mathrm{P} / \mathrm{H}$ & 04.47 & 06.59 & 17.52 & \multirow{15}{*}{17.63} \\
\hline & Calabar & 04.71 & 08.55 & 17.52 & \\
\hline & Uyo & 05.00 & 07.50 & 17.81 & \\
\hline & Umuahia & 05.25 & 07.30 & 18.05 & \\
\hline & Owerri & 05.29 & 07.20 & 18.51 & \\
\hline & Asaba & 06.11 & 06.45 & 18.38 & \\
\hline & Benin & 06.12 & 05.36 & 18.16 & \\
\hline & Enugu & 06.47 & 07.55 & 17.93 & \\
\hline & Ikeja & 06.58 & 03.33 & 18.33 & \\
\hline & Akure & 07.18 & 05.51 & 16.82 & \\
\hline & Ibadan & 07.43 & 03.90 & 18.16 & \\
\hline & Oshogbo & 07.46 & 04.95 & 13.57 & \\
\hline & Abeokuta & 07.95 & 03.21 & 18.91 & \\
\hline & Lokoja & 06.12 & 07.50 & 19.53 & \\
\hline & Makurdi & 07.43 & 08.32 & 19.88 & \\
\hline \multirow[t]{13}{*}{ North } & Illorin & 08.30 & 04.42 & 18.08 & \multirow{13}{*}{18.23} \\
\hline & Jalingo & 08.50 & 11.22 & 18.30 & \\
\hline & Abuja & 09.00 & 07.32 & 17.52 & \\
\hline & Yola & 09.12 & 12.29 & 19.64 & \\
\hline & Minna & 09.39 & 06.32 & 19.53 & \\
\hline & Jos & 09.87 & 04.97 & 12.84 & \\
\hline & Kaduna & 10.00 & 07.45 & 16.25 & \\
\hline & Bauchi & 10.37 & 09.80 & 18.21 & \\
\hline & Damaturu & 11.44 & 11.57 & 19.08 & \\
\hline & Maiduguri & 11.85 & 13.05 & 18.97 & \\
\hline & Kano & 12.00 & 08.31 & 16.52 & \\
\hline & Katsina & 12.15 & 07.30 & 17.72 & \\
\hline & Sokoto & 13.01 & 05.25 & 21.36 & \\
\hline
\end{tabular}

The difference in precipitable water indices in this zone is a clear indication of in- homogeneity of the ocean current intrusion to different locations and also an expression of distance in reducing the maritime characteristics of the ocean current. In the Northern zone, two assumptions could be the possible factors that contribute to the irregularity of the precipitable water indices with respect to latitudinal pattern. First, the areas with large land mass and low vegetation would experience high solar radiation, hence high surface temperature; high surface temperature results in high precipitable water. Second, the broken pattern of precipitable water indices with respect to latitudinal arrangement could also be caused by topographic effect: the lowest amounts of precipitable water are found in Plateau regions - Jos and Osogbo while high values of 
precipitable water are found in regions such as Sokoto, Damaturu and Maidugari which have plain terrain. Another interesting fact about the Northern zone is that air in the zone is not dry (table 2), though it lacks precipitation as compared to the Southern zone, the reason could be that air mass in this zone has high saturation deficits and stable atmospheric conditions.

Close examination of the map reveals that locations in the Northern zone that are at the boarder of water bodies have higher precipitable water indices than other locations including those in the Southern zone except Sokoto. These locations include Lokoja, Makurdi, Jalingo and Yola. This shows the resultant effect of high evaporation due to large land mass, low vegetation, closeness to water bodies and high solar intensity on the surface of these locations. Generally, on the average, the precipitable water index in the Southern zone is $17.63 \mathrm{~mm}$ while that of the Northern zone stands at $18.23 \mathrm{~mm}$ (table 2 ), and since the precipitable water index follows seasonal temperature, it could therefore be concluded that the Northern zone has higher temperature than the Southern zone.

\section{(ii) Precipitable Water Map}

The precipitable water map is designed to cover twenty eight locations in which meteorological data are available. The map is an average annual precipitable water covering ten years from 1989-1998, (fig.1). The distribution of precipitable water over the country follows seasonal temperature and atmospheric circulation pattern rather than latitude. From the map precipitable water appears to be higher in the Northern zone than in the South. Since the Northern zone has vast land mass and low vegetation, it shows therefore faster daily temperature change which affects seasonal temperature during the year's hence higher precipitable water.

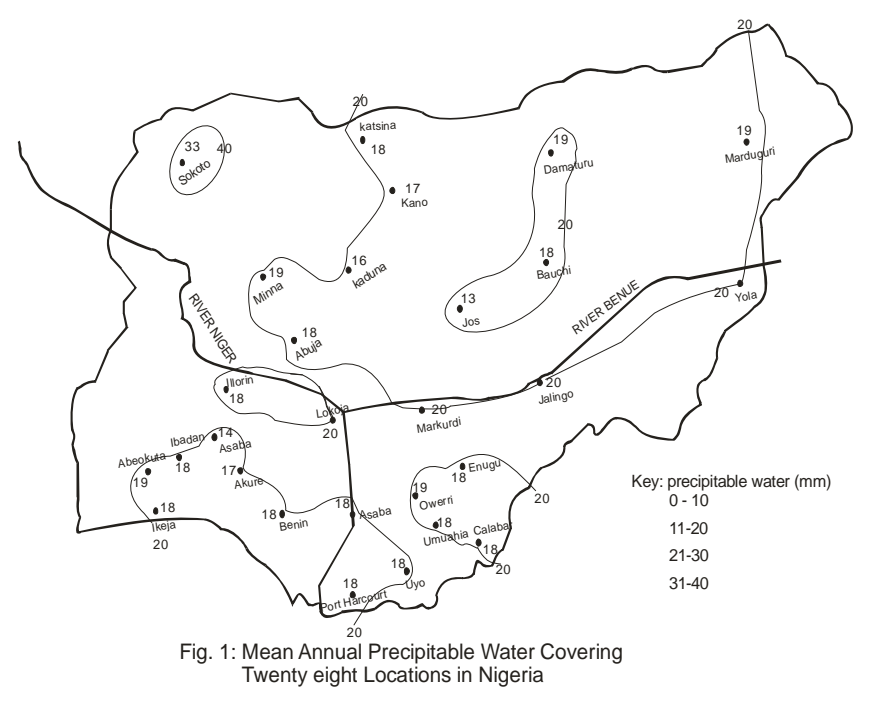

Another interesting difference between the Southern and the Northern zones is the distribution of the isolines. Southern zone has a more regular pattern while the Northern zone isolines exhibit broken pattern (Fig.1). This is also an indication of larger land mass in the Northern zone as compared to the Southern zone.

\section{ACKNOWLEDGEMENT}

The article is based on materials collected from Nigerian meteorological (NiMet) Agency-Abuja, Nigeria.

\section{CONCLUSION}

The foregoing discussion shows that the general pattern of the distribution of precipitable water in Nigeria is not as might be expected. The distribution is not an isolated phenomenon but is closely related with many other surface and atmospheric variables. The variables include surface and air temperature, net radiation, elevation, distance from ocean and location with respect to prevailing winds.

\section{REFERENCES}

(1) Adedokun J.A. 1986. On a relationship for estimating precipitable water vapour aloft from surface humidity over West Africa. J. Climatorol, 24 (6): 6-172 pp

(2) Akatsuka, S. Oyoshi, K and Tekeuchi, W. 2011. Development of precipitable water estimation method using MTSAT measurement. Journal of the Remote Sensing Society of Japan. ISSN: 0289-7911, vol. 31, N0. 5.481-489pp. www.rssj.or.jp/eng

(3) Foster J. and Bevis M. 2003. Lognormal Distribution of Precipitable Water in Hawii, Geochem. Geophys. Geosys. 4(7) 1065, doi:10,1029/2002 GC 000478

(4) Idemudia, G.O and Aro, T. O. 1997. Measurement of atmosphere precipitable water vapour at micrometer wave lengths over a tropical station. Nig.Journal of Physics. Vol.100p. http://www.nipng.org/author instructions.pdf

(5) Maduekwe A.A.L and Ogunmola A. 1997. Estimation of the monthly water vapour in Sokoto and its relationship with the horizontal global solar radiation. Nig. Journal of Physics, Vol. 9, 1999, 2022pp.http://www.nipng.org/author instructions.pdf

(6) Maduekwe A.A. and Iheonu E.E. 1999 Emperical determination of the monthly average atmosphere precipitable water distribution for Nine Nigerian locations, Nig. Journal of Renewable Energy. Vol 7, $1 \& 2$.

(7) Odouro-Afriyie, K., 1989: On the mean monthly equivalent potential temperature and rainfall in West Africa. Theor. Appl. Climatol. 39: 188-193pp.

(8) Trenberth E, Fasullo, J and Smith L. 2005. Trends variability in column - integrated atmospheric water vapour. Climate Dynam. 24, 741 - 758, doi: 10,1007/ s 0038 - 005-0017 - 4 .

(9) Wadge, G., Webley, PW, James, I. N. and co-authors 2002 Atmospheric models, GPS and InSAR measurements of the tropospheric water vapour field over mount Etna. Geophy.Res. Lett. 29 (19), 1905, doi: 10. 1029/ 2002 GL 015159 